\title{
A SPATIAL PATTERN ANALYSIS OF LANDSCAPE CHANGES BETWEEN 1956-1999 OF PINUS HALEPENSIS MILLER PLANTATIONS IN MONTES DE MALAGA STATE PARK (ANDALUSIA, SPAIN)
}

\author{
NAVARRO-CERRILLO, R.M.* - GUZMÁN-ÁLVAREZ, J.R. - \\ CLAVERO-RUMBAO, I. - CEACEROS, C. \\ ${ }^{I}$ Department of Forestry Engineering, University of Cordoba \\ Edf. Leonardo da Vinci, Campus de Rabanales \\ Mail Box 3048, 14080 Cordoba-Spain \\ (phone: 34-957-218657; fax: 34-957-218563) \\ *Corresponding author \\ e-mail:irlnacer@uco.es \\ (Received $5^{\text {th }}$ August 2010; accepted $7^{\text {th }}$ February 2013)
}

\begin{abstract}
Changes in forest diversity and the conversion of coniferous plantations into more natural woodlands are of the especial interest in the Mediterranean. The aim of this study was to investigate the changes in land use patterns and vegetation cover from 1956 to 1999 in Pinus halepensis Miller plantations in Montes of Malaga State Park (southern Spain). At a landscape level, a FRAGSTAT analysis was performed using aerial photograph series. At the community level, a total of 47 sample plots were analyzed. Field measurements indicate the presence of a total of 70 species in the different vegetation types sampled. Diversity indices showed a higher species richness for Aleppo pine plantations $(\mathrm{H}=1.54 \pm 0.2 ; \mathrm{D}=3.88 \pm 0.6)$, while Holm oak forests $(\mathrm{H}=1.37 \pm 0.1 ; \mathrm{D}=3.35 \pm 0.6)$ and agricultural land $(H=1.33 \pm 0.01 ; D=2.80 \pm 0.03)$ had lower values. FRAGSTATS analyses at landscape and class levels indicated increases in patch richness, number of patches, and percent of landscape mainly for pine plantations, Holm oak forests and shrub. Replacement of agricultural uses by conifer plantations led to a homogenization of landscape structure. This shift has modified the landscape by recovering a natural indigenous tree species, and improving the regeneration of Holm oak species, which are stabilizing and protecting the future establishment of native forests in this area. Our findings suggest that pine plantations could favour woody species diversity by increasing individual abundance and species richness in contrast to the situation in non forested agricultural land.
\end{abstract}

Key words: diversity, fragmentation, landscape metrics, vegetation cover, Mediterranean ecosystem.

\section{Introduction}

Mediterranean forests are quite unique ecosystems showing a high biodiversity content which have been identified as being a biological hotspot (Myers et al., 2000; Fabbio et al., 2003). This so-called anthropogenic agro-forest landscape (Bielsa et al., 2005; Jomaa et al., 2008) is also made up of natural and semi-natural systems such as shrub lands, pastures, and woods connected to each other with agricultural crops and a large proportion of plantations (Kreyer and Zerbe, 2006; Lasanta et al., 2006). Large areas of Spain's landscapes were covered by agricultural use in the last 50 years of the 20th century. This land was turned into forest plantations mainly with the aim of preventing soil erosion, and little attention was paid to the influence of this conversion on biodiversity. In particular, Aleppo pine (Pinus halepensis Miller) species dominate 43 percent of reforested areas in Spain (Vélez, 1986). 
Restoration actions are important silvicultural tools that can play a vital role in the protection and conservation of forest ecosystems (Kreyer and Zerbe, 2006; Mossler, 2006).

There is no simple answer to the question of whether forest plantations are good or bad for maintaining biodiversity (Mossler, 2006). For instance, little is known about the interactions of $P$. halepensis with woody species in plantations under Mediterranean climate (Maestre et al., 2003; Zavala and Zea, 2004). Moreover, the succession of pine plantations is different and unique compared to what occurs in similar, surrounding ecosystems (Sanz-Herráiz et al., 2002). There is an ongoing effort to manage coniferous plantations to ensure the modification of the landscape and its evolution to broadleaf forests (e.g. Atauri et al., 2005). Different conversion methods have been proposed including natural regeneration, which has shown itself to be a better alternative to the restoration of forest plantations (Mosser, 2006). Its success in coniferous plantations depends on many factors, both abiotic (light availability, microclimate and soil conditions) and biotic (sources of diaspores, seed dispersal agents, competition and browsing). The most common problem in extensive plantations seems to be the lack of seed trees of indigenous species, and a low light intensity due to a dense canopy (Hale, 2001), whereas overstory cover reduces the growth of herbaceous vegetation, and, consequently, its competition with tree seedlings (Diaci, 2002).

Information on species diversity in plantations has mainly compared it to that in natural forests, which are characterized by a great species richness (Swindel and Grosenbaugh, 1988; Amezaga and Onaindia, 1997; Brockerhoff et al., 2003, Puettmann and Berger, 2006). However, there has been relatively little research comparing plantation diversity with the agricultural land existing prior to forest plantations (Alados et al., 2004; Rocchini et al., 2006). We have done so in this study because plantations in Spain were mostly originally established on this type of land. Thus, an assessment of how the native biota reacts to the management changes generated by pine plantations is a crucial research need for policy makers. This study analyzes the changes in landscape patterns and vegetation cover from 1956 to 1999 in the Guadalmedina river basin (Southern Spain). It aims particularly to answer the following questions: (i) what was the role of Pinus halepensis plantations in the dynamic processes associated with the modification of the Mediterranean landscape? (ii) How have diversity indices changed at plant community level with regard to plantation activities?

\section{Methods}

\section{Study area}

The study was conducted in forested area of Montes of Malaga State Park (Andalusia) and adjacent agricultural areas (Guadalmedina watershed), in southern

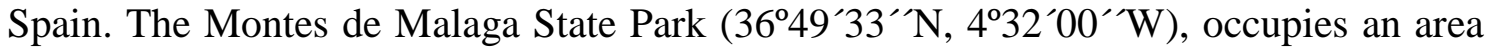
of about 4,995 ha, with calcarenite, clay and sandstone (leptisols and luvisols) being the main soil types (CSIC, 1989) (Figure 1). The elevation ranges from 90 to $1031 \mathrm{~m}$, and the maritime climate belongs to the mesa-Mediterranean and sub-humid climate conditions (Rivas Martinez 1987), characterised by mean annual temperatures of between 14 to $17.5^{\circ} \mathrm{C}$, with extreme values of between 3 to $30^{\circ} \mathrm{C}$, and mean annual precipitation ranging between $500-700 \mathrm{~mm}_{\text {year }}{ }^{-1}$. Land-use has changed considerably in the agricultural area surrounding the reserve, particularly since the 1930's, due to a forestation programme conducted by the Forest Department, and the decrease in 
traditional agricultural practices (e.g. terracing, grazing, cultivation of olive and almond groves, and crops).

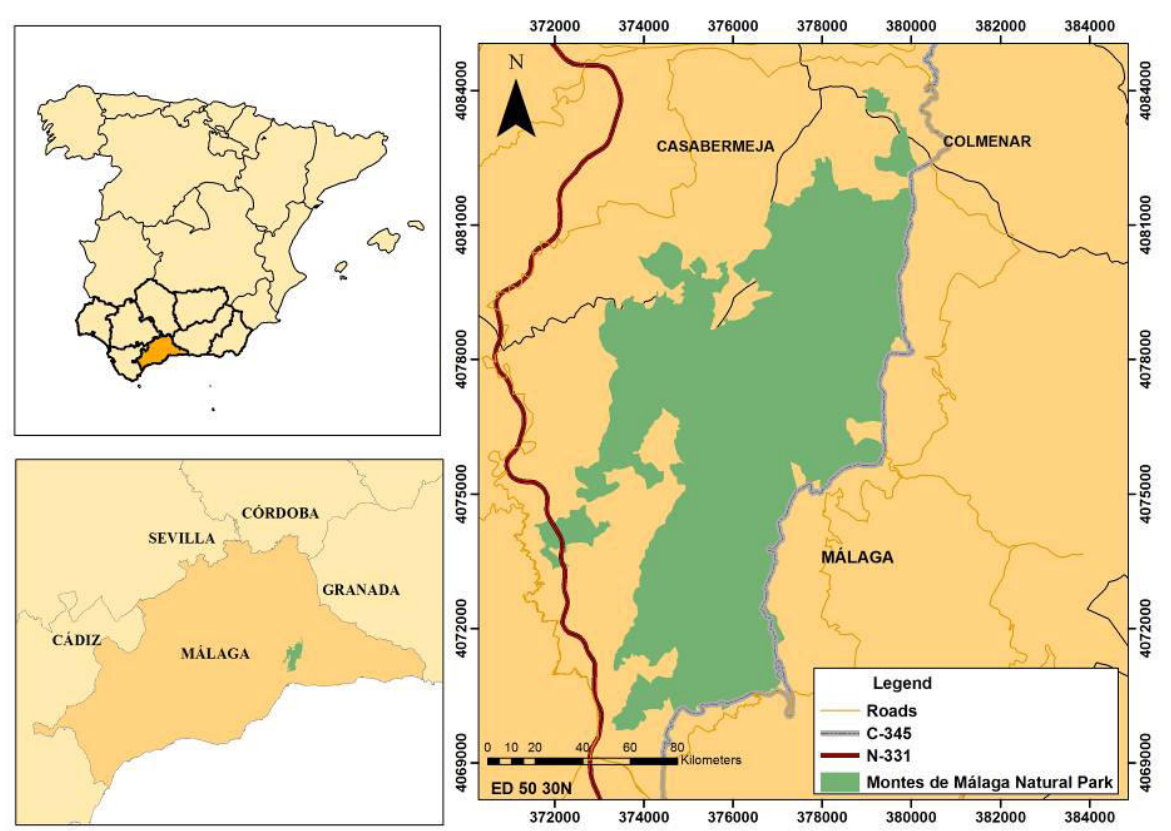

Figure 1. Location of the study area of Montes de Málaga State Park

The current vegetation found in the reserve comprises: semi-natural grasslands (Brachypodium retusum (Pers.) Beauv, Dactylis glomerata L.), shrublands (Ulex parviflorus Pourret, Rosmarinus officinalis L., Crataegus monogyna Jacq.); woodlands, e.g. Quercus ilex L. woodlands, mixed evergreen woodlands (dominated by Q. ilex, Q. suber L. and Olea europaea L. subsp. sylvestris Brot..), riparian woody vegetation (dominated by Populus alba L., Ulmus minor, Arbutus unedo L. and Salix sp.), and olive and almond orchards. Native conifers (Pinus halepensis Mill.), which reproduce spontaneously, were planted in the 1930's-1970's. The current tree cover of Montes de Malaga State Park is: pure Aleppo pine forest (60\%), mixed leppo pine and Oak species $(16.5 \%)$, mixed shrub and pasture land (15\%), and crops with little or no vegetation $(2.3 \%)$.

Using aerial photos and forest inventory data, we confirmed that the previous land uses in the forested area of Montes of Malaga National Park had been agricultural land. The study area, as well as including the Montes de Málaga State Park, was extended, establishing a limit running through infrastructures such as roads and physiographic characteristics of the relief, adding up to a total surface of 13,436 ha.

\section{Derivation of land-use maps}

Ortho aerial photographs taken in 1956 (grey-scale) and 1999 (colour) (scale: 1:33,000 and 1:10.000 respectively) were used (European datum 1950 Universal Transverse Mercator Huso 30). Each orthophoto was subjected to photo-interpretation (Consejería Medio Ambiente, 2003) by the same photo interpreter to reduce errors. This procedure was performed for each of the two periods (1956 and 1999); thus, each spatial unit represents a vegetation unit, whose identity may, potentially, change over time. A total of 50 landscape and vegetation types existing there between 1956 and 
1999 were merged into a total of 15 new representative landscape types, namely: 1-Pine (Pinus halepensis Miller) plantation (PP); 2-Pasture (PL); 3-Abandoned Olive tree (Olea europea L.) cultivation (OA); 4-Olive tree cultivation (OC); 5-Almond tree (Prunus dulcis [Mill.] D. A. Webb.) cultivation (AC);6-Abandoned Almond tree cultivation (AA); 7-Shrub (SL); 8-Cereals (GW); 9-Other cultivation (CC); 10- Holm oak (Quercus ilex L.) forest (HF); 11-Urban zone (UZ); 12-Industrial/infrastructure zone (IZ); 13-Wetlands (WL); 14-Other Agricultural land uses (AU); and 15-Other Forest land use (OF).

\section{Field sampling}

A field inventory was conducted in the agricultural area surrounding the reserve and in the Montes de Málaga State Park itself, to identify and verify the changes in vegetation and land use types from existing information in these areas. Data were collected during the months of July and August 2006 from a total of 47 sample plots representative of the following six main vegetation/land use types: pine plantation (PP) $(\mathrm{N}=5)$; Holm oak forest (HF) $(\mathrm{N}=6)$; shrub (SL) $(\mathrm{N}=15)$; abandoned Olive and almond tree cultivation $(\mathrm{OA})(\mathrm{N}=10)$; olive and almond tree cultivation $(\mathrm{AC})(\mathrm{N}=5)$; and pasture $(\mathrm{PL})(\mathrm{N}=6)$. The central point of each sample plot was referenced with a GPS hand-held unit to ensure accuracy and provide further post-analyses data. We randomly distributed the plots so that the total number of plots per stand varied between 5 and 15, depending on surface distribution. Each plot was defined by a circular parcel with a radius of $15 \mathrm{~m}$ (a surface of $706.96 \mathrm{~m}^{2}$ ). Variables inventoried included abundance of tree, shrub and herbaceous species. The tree parameters measured for each plot included: the diameter at breast height ( $\mathrm{DBH}$, taken $1.30 \mathrm{~m}$ above ground), number of trees per hectare $(\mathrm{NTH})$; tree height $(\mathrm{TH})(\mathrm{m})$ obtained with a hypsometer; and crown coverage $(\mathrm{CC})\left(\mathrm{m}^{2} \mathrm{ha}^{-1}\right)$, which was obtained from the projection on the four cardinal points, using a tape from the base of the tree. Understory shrub characteristics tallied number of individuals, average height $(\mathrm{m})$ and vegetation cover $(\%)$. Finally, the presence of herbaceous species and their percentage of cover $(\%)$ were noted. Plant species found during sampling were recorded as diversity indicators.

\section{Landscape analysis}

FRAGSTATS software, a landscape structure analysis program, was used to calculate various landscape metrics. This program, developed by the Forest Science Department, Oregon State University, U.S.A., has been widely used for quantifying landscape structure (McGarigal and Marks, 1995). This software produces a number of metrics: area, patch density, size and variability, edge, shape, core area, and diversity. FRAGSTATS is capable of computing more than 100 spatial statistics for quantifying landscape structure and spatial heterogeneity based on landscape composition and configuration. However, many of them are highly correlated (McGarigal and Marks, 1995). In this study, we selected 10 metrics for landscape level analysis and 6 metrics for class level analysis (Table 1). The selection was based on the review of previous studies (Tinker et al., 2003; Matsushita et al., 2005; Lasanta et al., 2006). The metrics chosen were used to characterize the spatial heterogeneity, fragmentation, complexity of patch shape, and connectivity for a given landscape. Brief definitions for the selected metrics are listed in Table 1 and the detailed definitions are given in the FRAGSTATS user's guide (McGarigal and Marks, 1995). It should be noted that number of patch (NP) and mean patch size (MPS) have to be used complementarily since high NP and 
low MPS values reinforce an interpretation of a fragmented landscape condition (Leitao and Ahern, 2002). The GIS platform used for visualization and spatial analysis was ArcGIS 9.2.

As a result, the use and compatibility of biodiversity indices and FRAGSTATS spatial analyses had the advantages of facilitating the evaluation and comparison of landscape change in forested areas of Montes of Malaga State Park and in the agricultural area surrounding the reserve from an ecological viewpoint.

Table 1. Landscape metrics used in this study and their brief definitions

\begin{tabular}{|c|c|}
\hline $\begin{array}{c}\text { Landscape } \\
\text { metrics (unit) }\end{array}$ & Description \\
\hline TA (ha) & $\begin{array}{l}\text { Total landscape area. TA equals the area of the landscape, and excludes the area } \\
\text { of any background patches within the landscape }\end{array}$ \\
\hline LPI (\%) & $\begin{array}{l}\text { Largest patch index. LPI equals the percentage of the landscape comprised by the } \\
\text { largest patch }\end{array}$ \\
\hline $\mathrm{NP}$ & $\begin{array}{l}\text { Number of patches. NP equals the number of patches in the land cover type or } \\
\text { landscape under investigation }\end{array}$ \\
\hline AREA MN (ha) & $\begin{array}{l}\text { Mean patch area. AREA MN equals the sum of the areas of all patches of the } \\
\text { corresponding patch type (or all patches in the landscape), divided by the number } \\
\text { of patches of the same type (or total number of patches) }\end{array}$ \\
\hline SHAPE AM & $\begin{array}{l}\text { Area-weighted mean shape index. SHAPE AM equals the average shape index of } \\
\text { patches of the corresponding patch type, weighted by patch area so that larger } \\
\text { patches are more relevant than smaller patches }\end{array}$ \\
\hline PR. & $\begin{array}{l}\text { Patch richness PR equals the number of different patch types present within the } \\
\text { landscape boundary }\end{array}$ \\
\hline SHDI & $\begin{array}{l}\text { Shannon's diversity index. SHDI equals minus the sum, across all patch types, of } \\
\text { the proportional abundance of each patch type multiplied by the proportion }\end{array}$ \\
\hline SHEI & $\begin{array}{l}\text { Shannon's evenness index. SHEI equals minus the sum, across all patch types, of } \\
\text { the proportional abundance of each patch type multiplied by that proportion, } \\
\text { divided by the logarithm of the number of patch types }\end{array}$ \\
\hline IJI (\%) & $\begin{array}{l}\text { Interspersion and juxtaposition index. IJI equals minus the sum of the length of } \\
\text { each unique edge type divided by the total landscape edge, multiplied by the } \\
\text { logarithm of the same quantity, summed over each unique edge type; divided by } \\
\text { the logarithm of the number of patch types times the number of patch types minus } \\
1 \text { divided by } 2\end{array}$ \\
\hline CONTAG $(\%)$ & $\begin{array}{l}\text { Contagion index. CONTAG equals } 1 \text { plus the sum of proportional abundance of } \\
\text { each patch type multiplied by number of adjacencies between cells of that patch } \\
\text { type and all other patch types, multiplied by the logarithm of the same quantity, } \\
\text { summed over each patch type; divided by } 2 \text { times the logarithm of the number of } \\
\text { patch types }\end{array}$ \\
\hline
\end{tabular}


Table 2. The transition matrix of the surface of landscape patch types (\%) in the agricultural area surrounding and inside the Montes de Málaga State Park from 1956 to 1999 (ha). (PP: Pine plantation; HF: Holm oak forest; SL: Shrub land; OC: Olive cultivation: OA: Abandoned olive cultivation; AA: Almond cultivation; PL: Pasture land).

\begin{tabular}{|c|c|c|c|c|c|c|c|c|c|}
\hline $\begin{array}{l}\text { Agricultural area surrounding the } \\
\text { Montes de Málaga State Park }\end{array}$ & 1999 & & & & & & & & \\
\hline 1956 & PP & PL & SL & $\mathrm{HF}$ & $\mathrm{AU}$ & $\mathrm{OAC}$ & $\mathrm{AC}$ & $\mathrm{OU}$ & Overall \\
\hline PP - Pine plantation & $51.00(98.7)$ & & $0.66(1.2)$ & & & & & & 51.66 \\
\hline PL - Pasture land & & $46.10(99.8)$ & $0.05(0.1)$ & & & & & & 46.15 \\
\hline SL - Shrub land & $161.27(4.5)$ & $1.75(0.1)$ & $2910.82(81.4)$ & & $2.03(0.1)$ & $450.11(12.6)$ & $6.72(0.19)$ & $40.17(1.1)$ & 3572.87 \\
\hline $\mathrm{HF}$ - Holm oak forest & & & & $36.44(100)$ & & & & & 36.44 \\
\hline $\mathrm{AU}-$ Agricultural and other uses & & & $78.63(36.8)$ & & $16.47(7.7)$ & $101.20(47.3)$ & & $17.22(8.1)$ & 213.52 \\
\hline $\begin{array}{l}\text { OAC - Olive and Almond cultivation } \\
\text { AC - Abandoned olive and almond }\end{array}$ & $31.40(0.71)$ & $41.10(0.9)$ & $997.67(22.3)$ & & $52.57(1.1)$ & $3134.43(70.2)$ & $135.90(3.0)$ & $71.42(1.6)$ & 4464.48 \\
\hline cultivation & & & & & & & $0.03(100)$ & & 0.03 \\
\hline $\mathrm{OU}$ - Other uses & & $1.16(2.1)$ & & & & & & $54.5397 .9)$ & 55.70 \\
\hline General total & 243.66 & 90.11 & 3987.84 & 36.44 & 71.07 & 3685.74 & 142.64 & 183.34 & 8440,85 \\
\hline $\begin{array}{l}\text { Forested area inside the Montes of } \\
\text { Malaga State Park } \\
\end{array}$ & 1999 & & & & & & & & \\
\hline 1956 & $\mathrm{PP}$ & PL & SL & $\mathrm{HF}$ & $\mathrm{AU}$ & $\mathrm{OAC}$ & $\mathrm{AC}$ & $\mathrm{OU}$ & Overall \\
\hline PP - Pine plantation & $1767.80(96.9)$ & $10.18(0.5)$ & $45.87(2.5)$ & & & & & & $1823.85(36.5)$ \\
\hline PL - Pasture land & & $2.32(5.3)$ & $27.10(62.6)$ & $3.45(7.9)$ & & $10.39(24.0)$ & & & $43.27(0.8)$ \\
\hline SL - Shrub land & $1209.21(56.6)$ & $17.92(0.8)$ & $887.73(41.6)$ & $6.59(0.3)$ & $0.08(0.003)$ & $3.59(0.1)$ & $5.22(0.2)$ & $2.42(0.1)$ & 2133.14 \\
\hline HF - Holm oak forest & & & $25.65(13.9)$ & $158.67(86.1)$ & & & & & 184.32 \\
\hline $\mathrm{AU}$ - Agricultural and other uses & & & $0.02(3.2)$ & & & $0.52(96.8)$ & & & 0.54 \\
\hline OAC - Olive and Almond cultivation & $368.66(45.8)$ & $3.69(0.4)$ & $215.96(26.8)$ & $36.45(4.5)$ & $0.04(0.004)$ & $145.01(18.0)$ & $15.59(1.9)$ & $19.23(2.4)$ & 804.63 \\
\hline $\begin{array}{l}\text { AC - Abandoned olive and almond } \\
\text { cultivation }\end{array}$ & & & & & & & 0 & & 0 \\
\hline OU - Other uses & & & $0.92(15.8)$ & & & & & $4.89(84.1)$ & 5.81 \\
\hline General total & 3345.67 & 34.11 & 1203.26 & 205.16 & 0.11 & 159.92 & 20.80 & 26.54 & 4995.56 \\
\hline
\end{tabular}




\section{Statistical analyses}

The richness (S), Shannon-Wiener (H), and Simpson's (D) of the tree and understory woody species were determined for each plot (Peet, 1975). Richness (S) was calculated as the total number of species, diversity (H) and (D) were determined using the Shannon-Wiener and Simpson's formulas. Differences between mean values for richness and diversity considered land use/vegetation type as the discriminating variables. All individual tree and shrub species appearing in the total number of plots were included in the analyses. Student's t-tests were performed to examine the differences between the richness and diversity indices between vegetation types described in the forested and agricultural areas. Significance levels at both 0.01 and 0.05 were reported.

Table 3. Mean values of richness (S, in number of species), Shannon-Wiener, and Simpson's diversity calculated for tree and woody understory species in the six types of sampled land use/vegetation types (PP: Pine plantation; HF: Holm oak forest; SL: Shrub land; OC: Olive cultivation: OA: Abandoned olive cultivation; AA: Almond cultivation; PL: Pasture land) in the agricultural area surrounding the reserve and forested area inside the Montes of Malaga State Park (Andalusia, southern Spain)

Agricultural area surrounding the Montes of Malaga State Park

\begin{tabular}{l|c|c|c|c}
\hline Types vegetation & N & Richness (S) & Shannon-Wiener index (H) & Simpson index (D) \\
\hline Pine plantation & - & - & - & - \\
\hline Pasture & 3 & $2.00 \pm 1.15$ & $0.52 \pm 0.33$ & $1.32 \pm 0.74$ \\
\hline Shrub & 7 & $7.20 \pm 0.71$ & $1.20 \pm 0.07 * *$ & $2.73 \pm 0.23$ \\
\hline Holm oak forest & 3 & $8.50 \pm 1.50 * *$ & $1.33 \pm 0.01 * *$ & $2.80 \pm 0.03$ \\
\hline $\begin{array}{l}\text { Olive and almond } \\
\text { cultivation }\end{array}$ & 5 & $1.20 \pm 0.44$ & $0.06 \pm 0.01$ & $1.04 \pm 0.04$ \\
\hline $\begin{array}{l}\text { Abandoned olive and } \\
\text { almond cultivation }\end{array}$ & 5 & $4.67 \pm 1.50$ & $1.05 \pm 0.13$ & $2.51 \pm 0.36$ \\
\hline
\end{tabular}

Forested area inside the Montes of Malaga State Park

\begin{tabular}{l|c|c|c|c}
\hline Pine plantation & 5 & $10.80 \pm 1.83$ & $1.54 \pm 0.20$ & $3.88 \pm 0.68$ \\
\hline Pasture & 3 & $9.50 \pm 2.50 * *$ & $1.45 \pm 0.19 * *$ & $2.71 \pm 0.61 * *$ \\
\hline Shrub & 8 & $8.20 \pm 1.24 \mathrm{~ns}$ & $1.06 \pm 0.13$ & $2.36 \pm 0.28 \mathrm{~ns}$ \\
\hline Holm oak forest & 3 & $7.33 \pm 0.88$ & $1.26 \pm 0.24$ & $2.96 \pm 0.65 * *$ \\
\hline $\begin{array}{l}\text { Olive and almond } \\
\text { cultivation }\end{array}$ & - & - & - & - \\
\hline $\begin{array}{l}\text { Abandoned olive and } \\
\text { almond cultivation }\end{array}$ & 5 & $7.00 \pm 1.08 * *$ & $1.37 \pm 0.19 \mathrm{~ns} \pm 0.62 \mathrm{~ns}$ \\
\hline
\end{tabular}

c Level of significance: n.s. non significant; $* *=P$-value $<0.05 ; *=P$-value $<0.01$.

\section{Results}

\section{Vegetation/land use change}

The land use and vegetation type map show the structure, land use distribution and evolution of the landscape from 1956 to 1999 in forested areas of Montes de Malaga State Park and in the agricultural area surrounding the reserve (Fig. 2).

The most significant change observed in Montes de Málaga State Park is that about $67 \%$ of the landscape belongs to pine plantations (Pinus halepensis Mill.) compared to 
$8 \%$ in the agricultural area surrounding the reserve. It is also important to note the increase of about 21 ha $(0.42 \%$ in the total surface of Montes de Málaga State Park) for Holm oak forest (Quercus ilex L.). These changes are mainly due to the indicated conversion of land use/vegetation types Olive tree (Olea europea L.) and Almond tree (Prunus dulcis [Mill.] D. A. Webb.) cultivation into pine plantations, Holm oak forests and other forest uses (Table 2).

The total of the surface undergoing changes in the agricultural area surrounding the Montes de Málaga State Park was of 2362.7 hectares (28\% of the whole surface). One of the most important events occurring in this area was the abandonment of agricultural activity, which signified a scrub overgrowing process, representing $22 \%$ of the surface of woody crops in 1956. In this regard, it should be noted that scrub derived from the olive grove conserved the tree cover of the olive trees, which remained alive after the abandonment, whereas the almond trees died shortly after being abandoned, leaving behind a treeless surface.

\section{Species richness and diversity}

Diversity values presented different values when considering the agricultural area surrounding the State Park and the area forested inside the reserve. A total of 56 woody species were recorded in canopy and mainly understory vegetation, with 31 occurring in forested areas and 25 in agricultural land, with 23 occurring in both areas. The mean species richness per vegetation type was significantly higher in the forested land in the abandoned olive and almond cultivation $(P=0.027$ : paired $T$-test $)$, in the Holm oak forests $(P<0.001)$ and in the pasture $(P<0.001)$ (Table 3$)$. Corresponding to the mean species richness, diversity indices grouped by vegetation types were also significantly higher in plantation forests (Table 3). In agricultural land, mean biodiversity indices calculated based on the field findings showed the greatest species richness (S) of land use/vegetation types for Holm oak forest $(\mathrm{HF}=8.5)$, shrub $(\mathrm{SL}=7.2)$, and abandoned olive and almond tree cultivation $(\mathrm{OA}=4.6)$, while olive and almond tree cultivation $(\mathrm{AA} / \mathrm{OC}=1.2)$ had the lowest species richness value (Table 3$)$. Despite the great species richness (S), Shannon-Wiener diversity index values suggest low evenness with only a slight variability for all land use/vegetation types ranging from 1.33 for Holm oak forest (HF) to 0.06 for olive and almond tree cultivation (AA/OC). Simpson's diversity index (D) values were indicative of higher for: Holm oak $(\mathrm{HF}=2.8)$ and shrub $(\mathrm{SL}=2.7)$, and lowest diversity values for olive and almond tree cultivation $(\mathrm{AA} / \mathrm{OC}=1.0)$ and pasture $(\mathrm{PL}=1.3)$. On the other hand, mean biodiversity indices for forested areas show the highest species richness value $(\mathrm{S})$ of land use/vegetation types for pine plantations $(\mathrm{PP}=10.8)$, pasture $(\mathrm{PL}=9.5)$, and shrub land $(\mathrm{SL}=8.2)$, while abandoned olive tree cultivation $(\mathrm{OA}=7)$ had the lowest species richness value (Table 3). These vegetation types showed Shannon-Wiener diversity index values with only a slight variability for all land use/vegetation types ranging from 1.5 for pine plantations (PP), 1.2 and Holm oak forest (HF) to 1.0 for shrub (SL). Simpson's diversity index (D) values were indicative of lower diversity values for shrub land $(\mathrm{SL}=2.3)$, and pasture $(\mathrm{PL}=2.7)$ and higher diversity values for pine plantations $(\mathrm{PP}=3.8)$, Abandoned olive and almond tree cultivation $(\mathrm{AA} / \mathrm{OA}=3.3)$ and Holm oak forest $(\mathrm{HF}=2.9)$. 
Table 4. Landscape metrics of 1956 and 1999 periods in the agricultural area surrounding the reserve and forested areas inside Montes of Malaga State Park (Andalusia, southern Spain)

\begin{tabular}{|c|c|c|c|c|c|c|c|c|c|c|}
\hline Year & TA (ha) & PR & NP & $\begin{array}{c}\text { AREA-MN } \\
\text { (ha) }\end{array}$ & LPI (\%) & $\begin{array}{c}\text { SHAPE AREA-WM } \\
\text { (ha) }\end{array}$ & IJI (\%) & $\begin{array}{c}\text { CONTAG } \\
(\%)\end{array}$ & SHDI & SHEI \\
\hline \multicolumn{11}{|c|}{ Agricultural area surrounding the Montes of Malaga State Park } \\
\hline 1956 & $8,440.79$ & 11 & 478 & 17.67 & 9.93 & 3.79 & 44.97 & 74.02 & 1.11 & 0.46 \\
\hline 1999 & $8,440.79$ & 13 & 555 & 15.21 & 9.90 & 3.62 & 50.57 & 72.53 & 1.26 & 0.49 \\
\hline \multicolumn{11}{|c|}{ Forested area inside the Montes of Malaga State Park } \\
\hline 1956 & $4,995.48$ & 9 & 274 & 18.23 & 21.19 & 3.51 & 56.37 & 67.42 & 1.30 & 0.59 \\
\hline 1999 & $4,995.48$ & 12 & 325 & 15.37 & 52.80 & 5.66 & 39.84 & 78.12 & 0.95 & 0.38 \\
\hline
\end{tabular}

TA (ha): total area of landscape; PR: patch richness (number of patches/100 ha); NP: number of patches; AREA-MN (ha): mean patch area; LPI (\%): largest patch index; SHAPE AREA-WM (ha): area-weighted mean shape index; IJI (\%): interspersion and juxtaposition index; CONTAG (\%): contagion index; SHDI: Shannon's diversity index; and SHEI: Shannon's evenness index. 


\section{Changes in landscape metrics at landscape level}

A comparison of the change in landscape metrics in 1956 and 1999 in both areas at the landscape level shows the following values (Table 4). The number of different patch types present within the forested area increased from 9 in 1956 to 12 land use types in 1999. This change is reflected in the values associated with the number of patches increasing from 274 in 1956 to 325 in 1999, and the decrease in mean patch area by about 3 ha. Additionally, LPI values showed a high increase from 21.19 to $52.8 \%$ indicating that the percentage of the landscape comprised by the largest patch increased by almost two-fold. Similarly, the area-weighted mean index in the study area also indicates a correlation between increases in the largest patch as the shape size changed from 3.51 to 5.66 .

The interspersion and juxtaposition indices became smaller while there was a greater contagion. This suggests that the different patch types became more poorly interspersed as small and dispersed patches decreased resulting in a lesser fragmentation of the landscape. However, the extent of landscape interspersion does not necessarily imply that patch types are dispersed. It is also important to note that IJI and CONTAG indices are inversely related.

Any indication of a decline in landscape heterogeneity was mainly due to the significant increase in land use type 1: Pine plantations (PP). Shannon's diversity and evenness indexes, both of which decreased, also suggest that the landscapes in the study area became less fragmented and more homogeneous at the landscape level.

In the agricultural area surrounding the Montes de Málaga State Park there was an increase in the number of tessellations (from 478 in 1956 to 555 in 1999), which had a direct repercussion on the decline in the relative surface index (AREA_MN) from 17.6 to 15.2 in the same period. The rise in IJI (44.9 in 1956 and 50.5 in 1999) and the diminution in the CONTAG (from 74.0 to 72.5) shows that the 1999 landscape was more fragmented and more heterogeneous than in 1956. The diversity indices increased in 1999, and so did the number of different use classes, rising from 11 in 1956 to 13 in 1999.

\section{Changes in landscape metrics at class level}

Tables 5 show the comparison of landscape metrics in 1956 and 1999 between the forested area in Montes of Malaga State Park and at the agricultural area surrounding the reserve at a class level. At the class level, the most significant change in Montes de Málaga State Park was that the percentage of landscape occupied in 1956 by cultivation of Almond and Olive tree species, and shrub land decreased significantly. Decrease amounts are as follows: Almond and Olive tree species (11\% in 1956 to 3\% in 1999, and 5\% in 1956 to less than 1\% in 1999), and shrub land (43\% in 1956 to $24 \%$ in 1999). These results reveal that the establishment of pine plantations occupied an increase from $37 \%$ in 1956 to $67 \%$ in 1999 in the landscape within the study area.

In 1956, the largest surface within the Montes de Málaga State Park was taken up by scrub, occupying 2130.9 ha equivalent to $43 \%$ of landscape (PLAND). In 1999, this diminished as a result of the change in its use to others such as: pine forest, abandoned olive groves, industrial and commercial zones and other forestry uses, which had not appeared in 1956. 


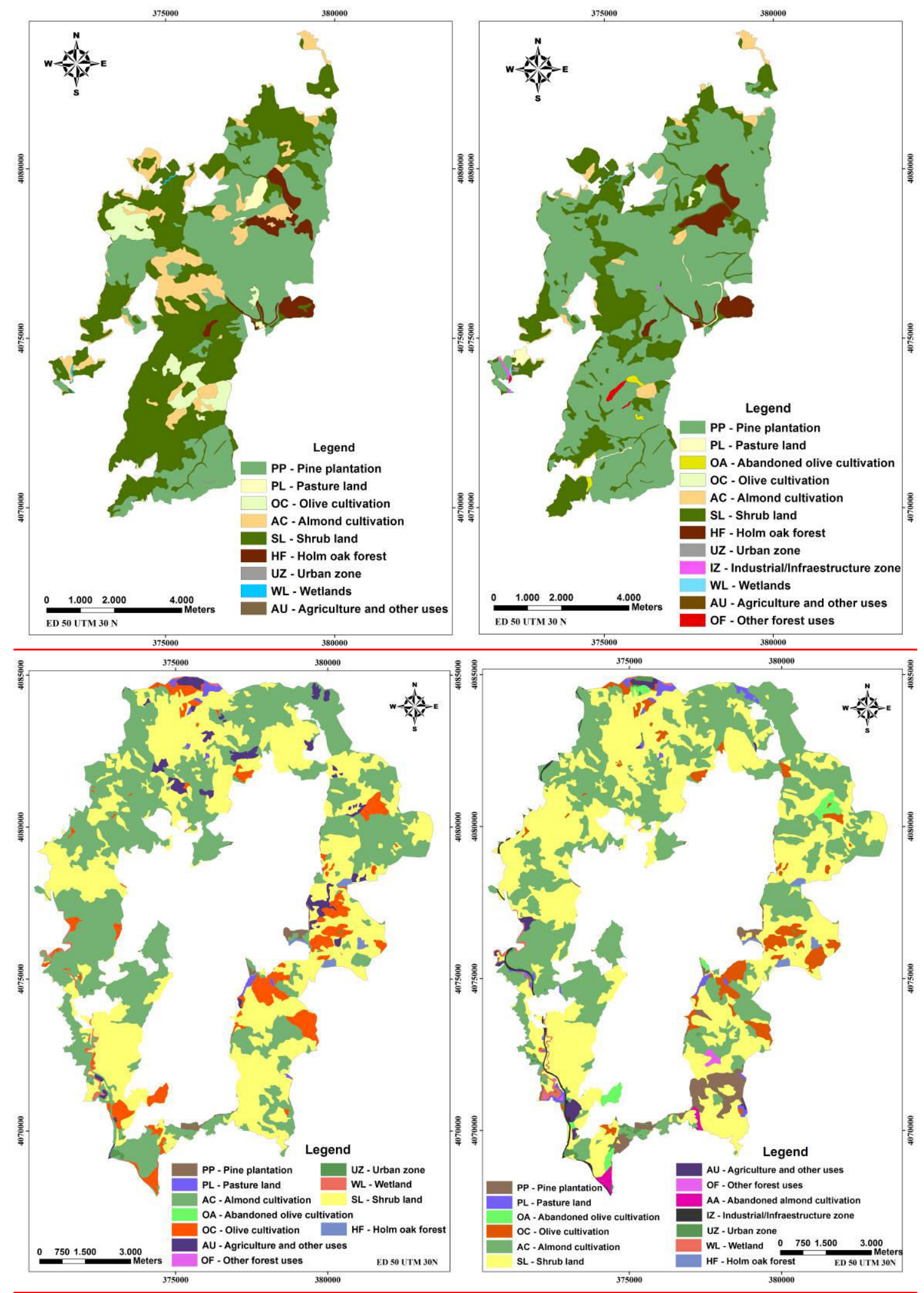

Figure 2. Changes in land use and vegetation cover from 1956 to 1999 of Montes de Málaga State Park and in the area surrounding the reserve (Andalusia, southern Spain). 
Pine plantation was the only patch type, whose area increased significantly, indicating a rapid rate of change. Also, the number of patches decreased for Pine plantation from 15 in 1956 to 12 in 1999 and for Holm oak forest from 8 in 1956 to 6 in 1999. In comparison, a total of 14 patch types within the study area, non-existent in 1956, appeared in 1999, i.e. Abandoned Olive cultivation (7 patches), other forest uses (3 patches), and Industrial/infrastructure zone (4 patches). Correspondingly, the mean patch area increased from 122 ha in 1956 to 279 ha in 1999 for Pine plantation, and from 23 ha in 1956 to 34 ha in 1999 for Holm oak forest. Similarly, when comparing all land use types with analogous area-weighted mean shape index values, Pine plantation shows the most significant change of less than 4 ha in 1956 to about 7 ha in 1999. The increased patch number and decreased mean patch area of Shrub and pasture suggest that these two landscapes also became more fragmented. The interspersion and juxtaposition indices for Pine plantation and Holm oak forest patch types both decreased from values of 57 and 51 in 1956 to 42 and 40 in 1999. These results indicate that other patch types were converted into new forest types, mainly Pine plantation and Holm oak from 1956 to 1999, and that these newly formed patches were more evenly distributed in the study area.

Around the Montes de Málaga State Park, the area taken up by scrubland increased from 3573.3 ha in 1956 to $3,987.8$ ha in 1999 , whereas the number of tessellations dropped from 159 to 140. Almond tree orchards occupied the largest surface in 1956. The landscape covered by almond trees diminished from $46 \%$ in 1956 to $39 \%$ in 1999 , the same as what happened with the insertion and juxtaposition index, which continued to fall from 1956 to 1999; on the contrary, the number of tessellations increased from 80 in 1956 to 87 in 1999.

The cause of this diminution, both in the surface and in the landscape percentage, was due to the transformation of the scrubland, the appearance of the use of abandoned almond trees, and to the development of industrial and commercial zones and technical infrastructures.

With regard to the use of abandoned crops (almonds and olives), these behaved identically in both cases due to the number of tessellations, the relative surface index and the insertion and juxtaposition index increasing in 1999. As can be observed in Table 5, abandoned almond trees were not used in 1956 but they were in 1999, and although the surface and number of tessellations, 31.25 and 2, respectively, were not very high, this made the relative surface index reach a high value. 
Table 5. Comparison of class metrics in 1956 and 1999 between the agricultural area surrounding the reserve and the forested areas inside of Montes of Malaga State Park (Andalusia, southern Spain)

\begin{tabular}{|c|c|c|c|c|c|c|c|c|c|c|c|c|}
\hline & & \multicolumn{2}{|c|}{$\begin{array}{c}\text { Percent of } \\
\text { Landscape (\%) }\end{array}$} & \multicolumn{2}{|c|}{ Class Area (ha) } & \multicolumn{2}{|c|}{ Number of Patches } & $\begin{array}{l}\text { Mean Patch Are } \\
\text { (ha) }\end{array}$ & \multicolumn{2}{|c|}{$\begin{array}{l}\text { Area-weighted Mean } \\
\text { Shape Index (ha) }\end{array}$} & \multicolumn{2}{|c|}{$\begin{array}{c}\text { Interspersion and } \\
\text { Juxtaposition Index }\end{array}$} \\
\hline \multicolumn{13}{|c|}{ Forested area inside the Montes de Malaga State Park } \\
\hline Land use & 1956 & 1999 & 1956 & 1999 & 1956 & 1999 & 1956 & 1999 & 1956 & 1999 & 1956 & 1999 \\
\hline $\mathrm{AC}$ & 10.86 & 2.91 & 542.27 & 145.26 & 139 & 126 & 3.90 & 1.15 & 2.71 & 2.01 & 51.39 & 36.59 \\
\hline $\mathrm{AU}$ & 0.01 & 0.00 & 0.71 & 0.05 & 8 & 2 & 0.09 & 0.03 & 2.39 & 1.34 & 31.05 & 28.91 \\
\hline $\mathrm{HF}$ & 3.69 & 4.11 & 184.13 & 205.15 & 8 & 6 & 23.02 & 34.17 & 2.17 & 1.91 & 50.83 & 42.13 \\
\hline IZ & - & 0.13 & - & 6.59 & - & 4 & - & 1.62 & - & 2.33 & - & 51.63 \\
\hline $\mathrm{OA}$ & - & 0.42 & - & 20.80 & - & 7 & - & 1.73 & - & 1.96 & - & 34.77 \\
\hline $\mathrm{OC}$ & 5.23 & 0.27 & 261.37 & 13.45 & 30 & 27 & 8.71 & 0.50 & 2.10 & 1.59 & 47.84 & 31.32 \\
\hline OF & - & 0.26 & - & 12.86 & - & 3 & - & 4.29 & - & 1.86 & - & 26.63 \\
\hline PL & 0.88 & 0.69 & 34.42 & 34.11 & 6 & 8 & 7.29 & 4.30 & - & 2.69 & 55.27 & 43.39 \\
\hline PP & 36.56 & 67.04 & 1826.34 & 3348.83 & 15 & 12 & 121.76 & 279.07 & 3.70 & 6.9 & 57.44 & 43.73 \\
\hline SL & 42.66 & 24.04 & 2130.98 & 1200.84 & 60 & 117 & 35.52 & 10.26 & 3.89 & 3.43 & 63.55 & 37.38 \\
\hline $\mathrm{UZ}$ & 0.02 & 0.05 & 1.03 & 2.67 & 3 & 8 & 0.38 & 0.33 & 2.59 & 1.40 & 35.65 & 32.10 \\
\hline WL & 0.10 & 0.10 & 4.80 & 4.80 & 5 & 5 & 0.96 & 0.96 & 2.23 & 2.23 & 29.48 & 48.32 \\
\hline \multicolumn{13}{|c|}{ Agricultural area surrounding the Montes de Malaga State Park } \\
\hline Land use & 1956 & 1999 & 1956 & 1999 & 1956 & 1999 & 1956 & 1999 & 1956 & 1999 & 1956 & 1999 \\
\hline $\mathrm{AC}$ & 46.19 & 39.44 & 3898.72 & 3328.90 & 80 & 87 & 48.73 & 38.26 & 3.97 & 3.60 & 51.12 & 36.15 \\
\hline AU & 2.53 & 0.84 & 213.44 & 71.20 & 33 & 14 & 6.47 & 5.09 & 1.88 & 1.57 & 30.95 & 27.34 \\
\hline $\mathrm{HF}$ & 0.43 & 0.43 & 36.56 & 36.56 & 16 & 16 & 2.29 & 2.29 & 1.51 & 1.51 & 50.76 & 39.76 \\
\hline $\mathrm{IZ}$ & - & 0.67 & - & 56.95 & - & 16 & - & 2.09 & - & 4.53 & - & 52.51 \\
\hline OA & 0.00 & 1.32 & 0.03 & 111.27 & 1 & 8 & 0.03 & 13.91 & 1 & 1.70 & - & 35.13 \\
\hline OC & 6.70 & 4.24 & 565.60 & 243.54 & 70 & 44 & 8.08 & 8.12 & 1.96 & 1.93 & 46.95 & 27.10 \\
\hline OF & 0.01 & 0.24 & 0.45 & 20.14 & 1 & 6 & 0.45 & 3.36 & 1.14 & 1.64 & - & 25.84 \\
\hline PL & 0.55 & 1.07 & 46.09 & 90.07 & 12 & 28 & 3.84 & 3.22 & 1.77 & 2.07 & 54.21 & 41.24 \\
\hline PP & 0.61 & 2.89 & 51.39 & 243.54 & 72 & 130 & 0.71 & 1.87 & 2.74 & 3.00 & 56.91 & 41.75 \\
\hline SL & 42.33 & 47.24 & 3573.35 & 3987.84 & 70 & 140 & 22.47 & 28.48 & 4.97 & 4.01 & 62.73 & 35.95 \\
\hline $\mathrm{UZ}$ & 0.18 & 0.68 & 15.24 & 57.61 & 10 & 41 & 1.52 & 1.41 & 1.49 & 1.65 & 30.01 & 31.95 \\
\hline WL & 0.47 & 0.57 & 39.92 & 47.99 & 16 & 23 & 1.66 & 2.09 & 2.93 & 3.07 & 29.63 & 49.24 \\
\hline AA & - & 0.37 & - & 31.25 & - & 2 & - & 15.63 & - & 0.65 & - & \\
\hline
\end{tabular}

AC: Almond cultivation; AU: Agriculture-other use; HF: Holm oak forest; IZ: Industrial/infrastructure zone; OA: Abandoned olive cultivation; OC: Olive cultivation; OF: Other forest use; PL: Pasture land; PP: Pine plantation; SL: Shrub land; UZ: Urban zone; WL: Wetlands 


\section{Discussion}

\section{Greater species richness in plantations}

Understanding species richness and biodiversity in restoration studies is important to identify and evaluate whether restoration goals have been met (Korb et al., 2003). In this study, species richness comparisons were those most valuable for capturing the whole image of the study area because what was considered were the numbers of species, not only the number of individuals. The results indicate that the species richness of forest plantations at the understory was higher than that of agricultural land representative of the situation before reforestation activities. These results indicate that the characteristics of understory vegetation of the plantation forests are similar to those of evergreen forests patches. The understory vegetation of pine plantations usually vanished before reforestation activities (Alvarez Calvente, 2001). Thus, differences in species diversity between these two types of land uses seem to be a result of habitat conversion. Consequently, the species present in forest plantations are considered to germinate from the soil seed bank or to be reintroduced from the surrounding forests.

According to Igarashi and Kiyono (2008), there are two possible reasons for the greater species richness in the plantations. First, silvicultural treatment of the forests plantations may have allowed a high diversity in the plantations. Generally, species richness increases in response to silvicultural treatments such as thinning (Battles et al., 2001). Pine canopy cover seems to be associated with biodiversity. Forest plantations with average percentages of canopy cover presented greater species richness than those uses with closer canopies. For Aleppo pine plantations in dry Mediterranean clima, Zavala and Zea (2004) also found that a more open plantation is accompanied by a greater oak abundance and species richness. This suggests that canopy cover is a key structural factor when designing and managing plantations to increase biodiversity. The forests surveyed have been correctly managed during the past 50 years (Consejería de Medio Ambiente, 2003), and the beneficial effects of thinning on natural regeneration can be assumed (Thomas et al., 1999). The soil seed bank (or re-sprouting capacity) or the amount of seed rain also affects the species richness of understory vegetation (Iida, 2006). In this case, the plantations were adjacent to natural forests, so that the seed rain would be higher than in the agricultural land. Therefore, the influence of the seed source on species richness should be considered as being relevant in plant plantations (Sakai et al., 2005). Climatic conditions (semiarid vs dry Mediterranean climate) together to seed sources disposal in the surrounding areas can justified differences found between this work and others researchs in semiarid Mediterranean areas in Iberian Peninsula (Maestre and Cortina, 2004, Bellot et al., 2004, Navarro-Cano et al., 2009).

This plant response suggests that habitat modifications generated by the plantations and silvicultural management may increase the richness and diversity of the understory flora._Furthermore, most plants in the understory plantations were at sampling growth stages despite the plantations being 50 or more years old. This suggests that the plant regeneration found in the plantations depended entirely on the seed bank (or resprouting capacity) recolonization from the surrounding native forest matrix. This recolonization was likely to only be possible because of the structural ensemble of natural vegetation patches and plantations. This tendency of a greater species richness in pine plantations has been observed in other Mediterranean areas (Zavala and Zea, 2004). These results suggest that forest plantations have the capacity for promoting 
improved ecosystem functionality, species composition and successional dynamics (Nagaike, 2002, Alados et al., 2004) compared to the surrounding agricultural land. Yet it is clear that many native species are unable to survive in the environment present in the crop plantations, and, at least in the case of most plants, they may not reproduce even if they establish themselves.

\section{Changes in landscape metrics}

Changes in land cover and in other ecosystem features have a direct impact on the social expectations from forests, especially their links with nature conservation, global climate changes, and recreation activities (Lasanta et al., 2006). Although the changes in forest landscape patterns are often subtle (Lawes et al., 2004), new actions are needed to identify the interrelationships between the future of planted forests and conservation in an evolutionary context. However, the lack of any consistent information on these artificial environments, and, in particular, on Pine plantations (Pinus halepensis Mill.) and their biological and ecological attributes, makes it difficult to understand the structure of their evolution and ecological components.

The land use/vegetation dynamics changed towards the recovery of forest cover when a large area (approximately 5,000 ha) of the Guadalmedina river basin and Montes de Málaga State Park region was converted (before the 1960's) from deforested slopes to mainly Aleppo pine plantations. Soil erosion and run-off distribution, which are directly related to the spatial distribution of vegetation (Martinez Mena et al., 2000), greatly decreased, increasing water infiltration and slope stability. A clear relationship between spatial vegetation pattern and dryland degradation have been showed by several authors (Kefi et al., 2007, Bautista et al., 2007).

Analyses of the process that has generated the patterns given in this study revealed that the establishment of $P$. halepensis species in Montes de Malaga State Park has successfully met all the corresponding silvicultural objectives. This particular pine species is, to a great extent, among those historically native to the Mediterranean region. The transition probability of the future dominant species has been indicated by the increase in the Holm oak surface naturally regenerating in the study area. It is highly probable that the regeneration sclerophiles species will facilitate and extend the formation of mixed forest stands (Sanz Herráiz et al., 2002) in Montes de Málaga. In addition, the regeneration success of Holm oak indicates that it is quite probable that an ecological recuperation will be obtained.

The effects of forest landscape changes on forest species can also be evidenced by fragmentation analysis. In general, the latter has important consequences for forest management because of the differently affected ecological processes (hydrological cycle, habitat dispersion, etc.). In Montes de Málaga State Park, major land use changes are due to the significant increase in pine plantations (1,522 ha) and Holm oak (21 ha), decreases in Shrub land (931 ha), Almond tree (Prunus dulcis [Mill.] D. A. Webb.) cultivation (396 ha), Olive tree (Olea europea L.) cultivation (248 ha) and pastureland ( 9 ha) between 1956 and 1999. Although fragmentation indices provide useful results on characteristic landscape patterns, they lack spatial information (the distribution of patches in the landscape) (Alados et al., 2004). Therefore, patches of a 'natural unevenness' will replace the 'regular evenness' of traditionally managed forests (Fabbio et al., 2003). Further, the fragmentation among private properties in Montes de Malaga State Park plays a key role as sites become unmanaged. 
FRAGSTATS analyses compute a broad spectrum of statistics that quantify many spatial aspects of maps that are intuitively apparent (Tinker et al., 2003). Although the indices generated are partially correlated, each of them may make a unique contribution to the interpretation of the different spatial pattern aspects for the uses studied (Garrabou et al., 1998). The results of this study correspond to the reality of a forest landscape that can be classified as being homogeneous on one scale and fragmented on another. Habitat connectivity has been identified as being one of the most important factors preserving dispersion among populations (Alados et al., 2004). So far, as reported in other studies (Fabbio et al., 2003; Atauri et al., 2005; Lasanta et al., 2006), it is not clear how Mediterranean ecosystem functions have changed in response to these landscape structure changes.

A combination of several approaches (landscape indices, multivariate analyses, and patch dynamic extraction) is recognized by many researchers as providing more comprehensive information on both temporal and spatial dynamics of landscapes (Pan et al., 1999). The landscape metrics calculated for Montes de Malaga and the transition maps of landscape patch types of between 1956 and 1999 were helpful tools for analyzing the changes in landscape/vegetation structure and composition, and developing effective forest management strategies. Notice that several metrics like those used on this research (e.g. Percent of landscape, class area, number of paches, mean pach area, area-weighted mean shape index, interseption and juxtaposition index) vary with scale resolution (Jelinski and $\mathrm{Wu}, 1996)$. However, when long term studios must to be conducted, analysis is limited by the availability of original scale of photographic material, and it has been used on several studies (Alados et al., 2004). Taken as a whole, FRAGSTATS was one more useful tool for understanding patterns which might affect forest biodiversity and other important ecological processes.

It can be concluded that land cover changes in Montes de Málaga underwent two important transformations. First, the increase in pine plantation and Holm oak as a result of forest restoration action, and, secondly, a reduction in Shrub land, Pasture land and Almond and Olive cultivation as a result of traditional land use abandonment and as a consequence of vegetation regressional and successional dynamics. Finally, the presence of other forest uses such as abandoned Olive cultivation, industrial/infrastructure, and urban areas may increase fragmentation and affect forest biodiversity in Montes de Málaga pine and regenerating oak stands.

A comparison of the landscape structure of the forested and agricultural land suggests that habitat heterogeneity was higher in the crop land than in the plantations. Several authors consider environmental heterogeneity to be an important factor, which promotes diversity (Rocchini et al., 2006; Jomaa et al., 2008). However, the higher structural heterogeneity of the agricultural land is made up of crop areas with a lesser diversity than is observed in forest plantations. On the contrary, the structural homogeneity of the plantations might cover a lower number of available niches but which include a greater diversity.

\section{Management implications}

In comparison to the previous adjacent agricultural land, the understory vegetation of plant plantations was characterized by having greater species richness, but a more homogeneous landscape structure. However, because forest succession is influenced by various factors such as land management practices, canopy cover or seed sources, further studies in regions with those elements are required to define the general 
relationship between potential and actual patterns in forest succession in plantations. Therefore, we suggest that a greater heterogeneity in canopy cover and vegetation types could increase biodiversity in conifer plantations in our study area.

Acknowledgements. This work was made possible with the help of the Environmental Department and Science and Innovation Department of Junta de Andalucía by the project "Gestión Sostenible de Bosque Mediterráneo-GESBOME", and by the coordinated Spanish MEC project INTERBOS (CGL2008-04503C03-01/BOS), as well as foresters of the Montes de Malaga State Park.

\section{REFERENCES}

[1] Alados, C.L., Pueyo, Y., Barrantes, O., Escós, J., Giner, L., Robles, A. (2004): Variations in landscape patterns and vegetation cover between 1957 and 1994 in a semiarid Mediterranean ecosystem. - Landscape ecology 19(5): 543-559.

[2] Alvarez Calvente, M. (2001): Paisaje Forestal Andaluz. Ayer y hoy. (Forest Landscape in Andalucía: Yesterday and today). - Junta de Andalucía-IBERSILVA, Sevilla.

[3] Amezaga, I., Onaindia, M. (1997): The effect of evergreen and deciduous coniferous plantations on the field layer and seed bank of native woodlands. - Ecography 20(3): 308318.

[4] Atauri, J.A., de Pablo, C.L., de Agar, P.M., Schmitz, M.F., Pineda, F.D. (2004): Effects of management on understory diversity in the forest ecosystems of northern Spain. Environmental management 34(6): 819-828.

[5] Battles, J.J., Shlisky, A.J., Barrett, R.H., Heald, R.C., Allen-Diaz, B.H. (2001): The effects of forest management on plant species diversity in a Sierran conifer forest. Forest ecology and management 146(1-3): 211-222.Bautista, S., Mayor, A., Bourakhouadar, J., Bellot, J. (2007): Plant spatial pattern predicts hillslope runoff and erosion in a semiarid mediterranean landscape. - Ecosystems 10(6): 987-998.

[6] Bellot, J., Maestre, F.T., Chirino, E., Hernández, N., Urbina, J.O. (2004): Afforestation with Pinus halepensis reduces ntive shrub performance in a Mediterranean semiarid area. - Acta oecologica 25(1-2): 7-15.

[7] Bielsa, I., Pons, X., Bunce, B. (2005): Agricultural abandonment in the North Eastern Iberian Peninsula: the use of basic landscape metrics to support planning. - Journal Environmental Planning and Management 48(1): 85-102.

[8] Brockerhoff, E.G., Ecroyd, C.E., Leckie, A.C., Kimberley, M.O. (2003): Diversity and succession of adventine and indigenous vascular understorey plants in Pinus radiata plantation forests in New Zealand. - Forest Ecology and Management, 185(3): 307-326.

[9] Burnett, C., Blaschke, T. (2003): A multi-scale segmentation object relationship modelling methodology for landscape analysis. - Ecological Modelling 168(3): 233-249.

[10] Consejería de Medio Ambiente (2003): Plan de Ordenación de los recursos naturales y el plan rector de uso y gestión del Parque natural montes de Málaga. (Management Plan of Natural Resources of Montes de Malaga State Park) - Consejería de Medio Ambiente, Junta de Andalucía, Sevilla.

[11] CSIC (1989): Mapa de Suelos de Andalucía. - Junta de Andalucía, Sevilla.

[12] Diaci, J. (2002): Regeneration dynamics in a Norway spruce plantation on a silver fir beech forest site in the Slovenia Alps. - Forest Ecology and Management 161(1-3): 27 38 .

[13] Fabbio, G., Merlo, M., Tosi, V. (2003): Silvicultural management in maintaining biodiversity and resistance of forests in Europe-the Mediterranean region. - Journal of Environmental Managemet 67(1): 67-76.

[14] Garrabou, J., Riera, J., Zabala, M. (1998): Landscape pattern indices applied to Mediterranean subtidal rocky benthic communities. - Landscape ecology 13(4): 225-247. 
[15] Gotelli, N.J., Colwell, R.K. (2001): Quantifying biodiversity: procedures and pitfalls in the measurement and comparison of species richness. - Ecology Letters 4(4): 379-391.

[16] Hale, S.E. (2001): Light regime beneath Stika spruce plantations in northern Britain: preliminary results. - Forest Ecology and Management 151(1-3): 61-66.

[17] Iida, S. (2006): Dispersal patterns of Quercus serrata acorns by wood mice in and around canopy gaps in a temperate forest. - Forest Ecology and Management 227(1-2): 71-78.

[18] Igarashi, T., Kiyono, Y. (2008): The potential of hinoki (Chamaecyparis obtusa [Sieb. et Zucc.] Endlicher) plantation forests for the restoration of the original plant community in Japan. - Forest Ecology and Management 255(1): 183-192.

[19] Ito, S., Nakagawa, M., Buckley, G., Nogami, K. (2003). Species richness in sugi (Cryptomeria japonica D. DON) plantations in south-eastern Kyushu, Japan: the effects of stand type and age on understory trees and shrubs. Journal of Forest Research 8 (1), 49-57.

[20] Jelinski, D.E., Wu, J. (1996): The modifiable area unit problem and implications for landscape ecology. - Landscape Ecology 11(3): 129-140.

[21] Jomaaa, I., Audab, Y., Abi Salehc, B., Hamze, M., Safi, S. (2008): Landscape spatial dynamics over 38 years under natural and anthropogenic pressures in Mount Lebanon. Landscape and urban planning 87(1): 67-75.

[22] Kefi, S., Rietkerk, M., Alados, C., Pueyo, Y., Papanastasis, V., Elaich, A., de Ruiter, P. (2007): Spatial vegetation patterns and imminent desertificatiion in Mediterranean arid ecosystems. - Nature 449: 213-217.

[23] Korb, J.E., Covington, W.W., Fulé, P.Z. (2003): Sampling techniques influence understory plant trajectories after restoration: an example from Ponderosa pine restoration. - Restoration ecology 11(4): 504-515.

[24] Kreyer, D., Zerbe, S. (2006): Short-lived tree species and their role as indicators for plant diversity in the restoration of natural forests. - Restoration ecology 14(1): 137-147.

[25] Lasanta, T., Gonzalez-Hidalgo, J.C., Vicente-Serrano, S., Sferi, E. (2006): Using landscape ecology to evaluate an alternative management scenario in abandoned Mediterranean mountain areas. - Landscape and urban planning 78(1-2): 101-114.

[26] Lawes, M.J., MacFarlane, D.M., Eeley, H.A. (2004): Forest landscape pattern in the KwaZulu-Natal midlands, South Africa: 50 years of change or stasis? - Austral ecology 29(6) : 613-623.

[27] Leitao, A.B., Ahem, J. (2002): Applying landscape ecological concepts and metrics in sustainable landscape planning. - Landscape and urban planning 59(2): 65-93.

[28] Maestre, F.T., Cortina, J., Bautista, S., Bellot, J. (2003): Does Pinus halepensis facilitate the establishment of shrubs in Mediterranean semi-arid afforestations? - Forest Ecology and Management 176(1-3): 147-160.

[29] Maestre, F.T., Cortina, J. (2004): Are Pinus halepensis plantations useful as a restoration tool in semiarid Mediterranean areas? - Forest Ecology and Management 198(1-3): 303317.

[30] Martínez-Mena, M., Castillo, V., Albaladejo, J. (2001): Hydrological and erosional response to natural rainfall in a semi-arid area of south-east Spain. - Hydrological processes 15(4): 557-571.

[31] Matsushita, B., Xu, M., Fukushima, T. (2005): Characterizing the changes in landscape structure in the Lake Kasumigaura Basin, Japan using a high-quality GIS dataset. Landsc. urban plan. 78(3): 241-250.

[32] McGarigal, K., Marks, B.J. (1995): FRAGSTATS: spatial pattern analysis program for quantifying landscape structure. - USDA Forest Service General Technical Report PNW351. Corvallis, Oregon, U.S.A.

[33] Mossler, A. (2006). Recovery of native biodiversity under forest plantations. Forest health and biodiversity news 10 (1), 1-5.

[34] Myers, N., Mittermeier, R.A., Mittermeier, C.G., Fonseca, G.A., Kent, J. (2000): Biodiversity hotspots for conservation priorities. - Nature 403: 853-858. 
[35] Nagaike, T. (2002): Differences in plant species diversity between conifer (Larix kaempferi) plantations and broad-leaved (Quercus crispula) secondary forests in central Japan. - Forest Ecology and Management 168(1-3): 111-123.

[36] Navarro-Cano, J.A., Barberá, G.G., Ruiz-Navarro, A., Castillo, V.M. (2009): Pine plantation bands limit seedling recruitment of a prennial Grass under semiarid conditions. - Journal of Arid Enviroment 73(1): 120-126.

[37] Pan, D., Domon, G., de Blois, S., Bouchard, A. (1999): Temporal (1958-1995) and spatial patterns of land use changes in Haut-Saint-Laurent (Québec, Canada) and their relation to landscape physical attributes. - Landscape ecology 14(1): 35-52.

[38] Peet, R.K. (1975): Relative diversity indices. - Ecology 56(2): 496-498.

[39] Puettmann, K.J., Berger, C.A. (2006): Development of tree and understory vegetation in young Douglas-Fir plantations in western Oregon. - Western Journal of Applied Forestry 21(2): 94-101.

[40] Rivas Martínez, S. (1987): Memoria del Mapa de Series de Vegetación de España. (Vegetation Map of Spain). - ICONA, Ministerio de Agricultura, Pesca y Alimentación. Madrid.

[41] Rocchini, D., Perry, G.L., Salerno, M., Maccherini, S., Chiarucci, A. (2006): Landscape change and the dynamics of open formations in a natural reserve. - Landscape and urban planning 77(1-2): 167-177.

[42] Sakai, A., Sato, S., Sakai, T., Kuramoto, S., Tabuchi, R. (2005): A soil seed bank in a mature conifer plantation and establishment of seedlings after clearcutting in southwest Japan. - Journal of forest research 10(4): 295-304.

[43] Sanz Herráiz, C., López Estébanez, N., Molina Holgado, P. (2002): Influencia de las repoblaciones forestales en la evolución de las comunidades vegetales y orníticas de la Sierra de los Filabres (Almería). - Ería 58: 157-176.

[44] Swindel, B.F., Grosenbaugh, L.R. (1988): Species diversity in young Douglas-fir plantations compared to old growth. Forest Ecology and Management 23(2-3): 227-231.

[45] Thomas, S.C., Halpern, C.B., Falk, D.A., Liguori, D.A., Austin, K.A. (1999): Plant diversity in managed forests: understory responses to thinning and fertilization. Ecological application 9(3): 864-879.

[46] Tinker, D.B., Romme, W.H., Despain, D.G. (2003): Historic range of variability in landscape structure in subalpine forests of the Grater Yellowstone Area, USA. Landscape ecology 18(4): 427-439.

[47] Vélez, R. (1986): Fire prevention in Aleppo pine forests. Options mediterraneennes 1: 167-178.

[48] Zavala, M.A., Zea, E. (2004): Mechanisms maintaining biodiversity in Mediterranean pine-oak forests: insight from a spatial simulation model. - Plant ecology 171(1-2): 197207. 